\title{
Opinions of West Texas pharmacists about emergency contraception
}

Gary SUTKIN, Brenda GRANT, Brian K. IRONS, Tyrone F. BORDERS.

\begin{abstract}
*
Background: The pharmacist's role in dispensing emergency contraception (EC) has become controversial due to the intersection of personal and professional ethics. Therefore, to examine the issue of EC availability, we surveyed a sample of West Texas pharmacists. West Texas is a religiously and politically conservative region where no methods of EC have been made available.

Objective: to survey a sample of pharmacists in West Texas about their experience, beliefs, and knowledge of EC both before and after a presentation of the current literature about EC. Methods: We asked a convenience sample of 75 pharmacists about their experience, beliefs, and knowledge of EC both before and after a presentation of the current literature about EC. Results: Sixty-four (85\%) pharmacists agreed to complete the study questionnaire. None carries EC in his/her pharmacy, and scientific understanding of EC was generally poor. Fourteen percent stated EC conflicts with their religious views, $17 \%$ considered it a method of abortion, $11 \%$ would not be willing to fill an EC prescription written by a doctor. $58 \%$ would be willing to offer EC over the counter. The presentation encouraged more to offer it over the counter, but in general did not significantly change their beliefs.

Conclusion: Our sample of West Texas pharmacists demonstrated very little experience with, a general lack of knowledge about, and some personal and religious objections to EC.
\end{abstract}

Keywords: Contraception, Postcoital. Pharmacists. Ethics, Pharmacy. United States.

\footnotetext{
"Gary SUTKIN. MD, MBA Assistant Professor, Departments of Obstetrics and Gynecology. University of Pittsburgh, Magee-Womens Hospital, Pennsylvania (USA).

Brenda GRANT. Resident, Department of Family Medicine, University of lowa at Cedar Rapids. lowa (USA). Brian K. IRONS. Associate Professor, Pharmacy Practice at the Texas Tech University Health Sciences Center. Texas (USA).

Tyrone F. BORDERS. Associate Professor, Department of Health Policy and Management, Fay W. Boozman College of Public Health, University of Arkansas for Medical Sciences. Arkansas (USA).
}

\begin{abstract}
RESUMEN
Antecedentes: El papel del farmacéutico dispensando contraceptivos de emergencias (CE) es controvertido debido a la intersección de la ética personal y profesional. Así que para examinar el problema de la disponibilidad de CE investigamos una muestra de farmacéuticos de West Texas. West Texas es una región religiosa y políticamente conservadora donde no están disponibles métodos de CE.

Objetivo: Investigar una muestra de farmacéuticos de West Texas sobre sus experiencias, creencias y conocimiento de $\mathrm{CE}$ antes y después de una presentación sobre la literatura actual sobre CE. Métodos: Preguntamos a una muestra de conveniencia de 75 farmacéuticos sobre sus experiencias, creencias y conocimiento sobre $\mathrm{CE}$ antes y después de una presentación de la literatura actual sobre CE.

Resultados: Sesenta y cuatro (85\%) farmacéuticos aceptaron completar el cuestionario del estudio. Ninguno posee CE en su farmacia, y el conocimiento científico de la CE era realmente pobre. El catorce por ciento afirmó que la $\mathrm{CE}$ colisiona con sus creencias religiosas, el $17 \%$ lo consideró un método de aborto, el $11 \%$ no era capaz de dispensar una receta de CE escrita por un médico. El 58\% sería capaz de ofrecer CE de libre venta. La presentación animó a ofrecerla como libre venta, pero en general no cambió sus creencias significativamente.

Conclusión: Nuestra muestra de farmacéuticos de West Texas demostró muy poca experiencia, una falta general de conocimientos y algunas objeciones personales y religiosas sobre la CE.
\end{abstract}

Palabras clave: Contracepción postcoital. Farmacéuticos. Ética, farmacia. Estados Unidos.

\section{(English)}

\section{INTRODUCTION}

Hormonal emergency contraception (EC), also called post-coital contraception, is used after unprotected intercourse to prevent pregnancy. Recent controversy has stemmed from news reports of pharmacists refusing to dispense EC due to their right to exercise their conscience to refuse to dispense a prescription in morally objectionable situations. $^{1-3}$ Some of the controversy may be a result of that fact that the mechanism of action of EC is not precisely known. ${ }^{4}$ While the prevailing evidence suggests that it prevents conception by preventing or delaying ovulation ${ }^{5-7}$ there is some 
evidence to support that it may also work to prevent implantation. ${ }^{8,9}$

This controversy has caught the attention of professional organizations, $^{10}{ }^{12}$ pharmacists, ${ }^{11}$ ethicists $^{2}$, and legislators. ${ }^{12}$ Physicians, ${ }^{13}$ midwives, ${ }^{14}$ and patients ${ }^{15,16}$ have been surveyed regarding their beliefs, and reports have been generated about pharmacist participation in statewide collaborative drug therapy agreements in Washington and Minnesota. ${ }^{17,18}$ Yet we are aware of only one survey of the knowledge and beliefs of American retail pharmacists. The survey was from New Mexico, and EC was already widely available at the time it was conducted. ${ }^{19}$

We undertook our survey in order to ascertain EC beliefs and knowledge from a group of pharmacists in West Texas, which is a religiously and politically conservative region where EC is not available. Lubbock county has approximately 207,000 residents. $27 \%$ are Hispanic or Latino, and $9 \%$ are black. Another 600,000 West Texas residents live in the surrounding counties. ${ }^{20}$ We are not aware of any pharmacies in Lubbock county or in the surrounding West Texas counties that carry Preven or Plan B (proprietary forms of EC).

Our objective was to survey a sample of pharmacists in West Texas about their experience, beliefs, and knowledge of EC both before and after a presentation of the current literature about EC.

\section{METHODS}

This study was approved by both the West Texas Pharmacists Association (WTPA) and the Texas Tech University Health Sciences Center Institutional Review Board. The WTPA is a professional organization with 400 to 500 members. Its membership includes approximately $20 \%$ of the pharmacists practicing in West Texas. The average age of its members is approximately 50 years old, and $85-90 \%$ of members are male. The majority of members practice in independent retail pharmacies.

One of the authors (GS) was invited to give a presentation on EC, the biologic studies examining its mechanism of action, and the clinical studies examining its efficacy and safety at the WTPA meeting on September 22, 2003. Prior to and after listening to a 40 minute presentation of the current literature on EC and with informed consent, all 75 attendees of the presentation were given a written survey assessing demographic variables and their experience with, knowledge of, and beliefs about EC. The survey was created by the authors. Participation in the survey was anonymous and voluntary. Demographic variables and answers to the survey questions were calculated using simple frequencies. We tested for differences in the proportions of respondents' answers before and after the talk by conducting chi-square analyses. Because the surveys were completed anonymously, we did not have the ability to match pre- and postanswers.

\section{RESULTS}

Sixty-four $(85 \%)$ of the 75 pharmacists who attended the WTPA meeting completed the questionnaire. Table 1 lists characteristics of the 64 respondents, who had a mean age of 60 (range 3686; mean age of male respondents was 64 ; mean age of female respondents was 47 ). $77 \%$ of our respondents were from Lubbock's surrounding counties, i.e.: primarily rural areas of West Texas. Of the 11 respondents who stated their practice is ten or more miles from the next pharmacist, 10 $(91 \%)$ work in independent retail pharmacies and 1 (9\%) gave no response. Of the 52 who stated their practice is less than ten miles from the next pharmacist, 21 (40\%) work in independent retail pharmacies, $15(29 \%)$ work in chain retail pharmacies, and $16(31 \%)$ work in hospitals or other institutions. One gave no response.

\begin{tabular}{|c|c|c|}
\hline Gender & $\mathrm{n}$ & $\%$ \\
\hline Male & 48 & $75 \%$ \\
\hline Female & 16 & $25 \%$ \\
\hline \multicolumn{3}{|l|}{ Type of Pharmacy } \\
\hline Independent Retail Pharmacy & 31 & $48 \%$ \\
\hline Chain Pharmacies & 15 & $23 \%$ \\
\hline Closed-care Facilities* & 9 & $14 \%$ \\
\hline Other** & 9 & $14 \%$ \\
\hline \multicolumn{3}{|l|}{ Practice Location } \\
\hline Lubbock County & 13 & $20 \%$ \\
\hline Surrounding County & 49 & $77 \%$ \\
\hline Nonrespondents & 2 & $3 \%$ \\
\hline \multicolumn{3}{|l|}{ Remoteness of Practice Location } \\
\hline Within $10 \mathrm{mi}$ of another pharmacy & 52 & $80 \%$ \\
\hline 10-24 miles from nearest pharmacy & 4 & $6 \%$ \\
\hline 25 to $49 \mathrm{mi}$ from nearest pharmacy & 7 & $11 \%$ \\
\hline Nonrespondent & 1 & $2 \%$ \\
\hline
\end{tabular}

None of the 64 respondents carries any form of proprietary EC (in the form of Preven and Plan B) in his or her pharmacy, has been asked by either a patient or a physician about EC in the previous 12 months, nor have they ever filled a prescription for EC. Yet when asked about their exposure to potential candidates for EC, $8(13 \%)$ had seen a woman reporting a recent rape, $15(23 \%)$ had seen a woman reporting a broken condom, and 60 (94\%) had seen a woman report missing some oral contraceptive pills. Five respondents $(8 \%)$ worked for a pharmacy with a policy on the provision of post-coital contraception with a prescription, even though EC was not carried.

Table 2 summarizes the knowledge of our surveyed pharmacists before the talk. Table 3 summarizes the beliefs of our surveyed pharmacists before and after the talk. Before the presentation, seven of the 45 that would fill a prescription written by a physician would not give it OTC. Seven out of the 14 not willing to provide EC over the counter (OTC) indicated a religious objection. The other 7 had no religious objection to EC. All of the 45 who did not object to EC on religious grounds were willing to fill EC prescriptions written by a physician. 39 of these 45 would also give EC OTC. Only $73 \%$ of respondents indicated they would give EC to a rape victim. The presentation did not significantly change 
their beliefs with exception of an increased willingness to provide EC OTC $(p=0.04)$.

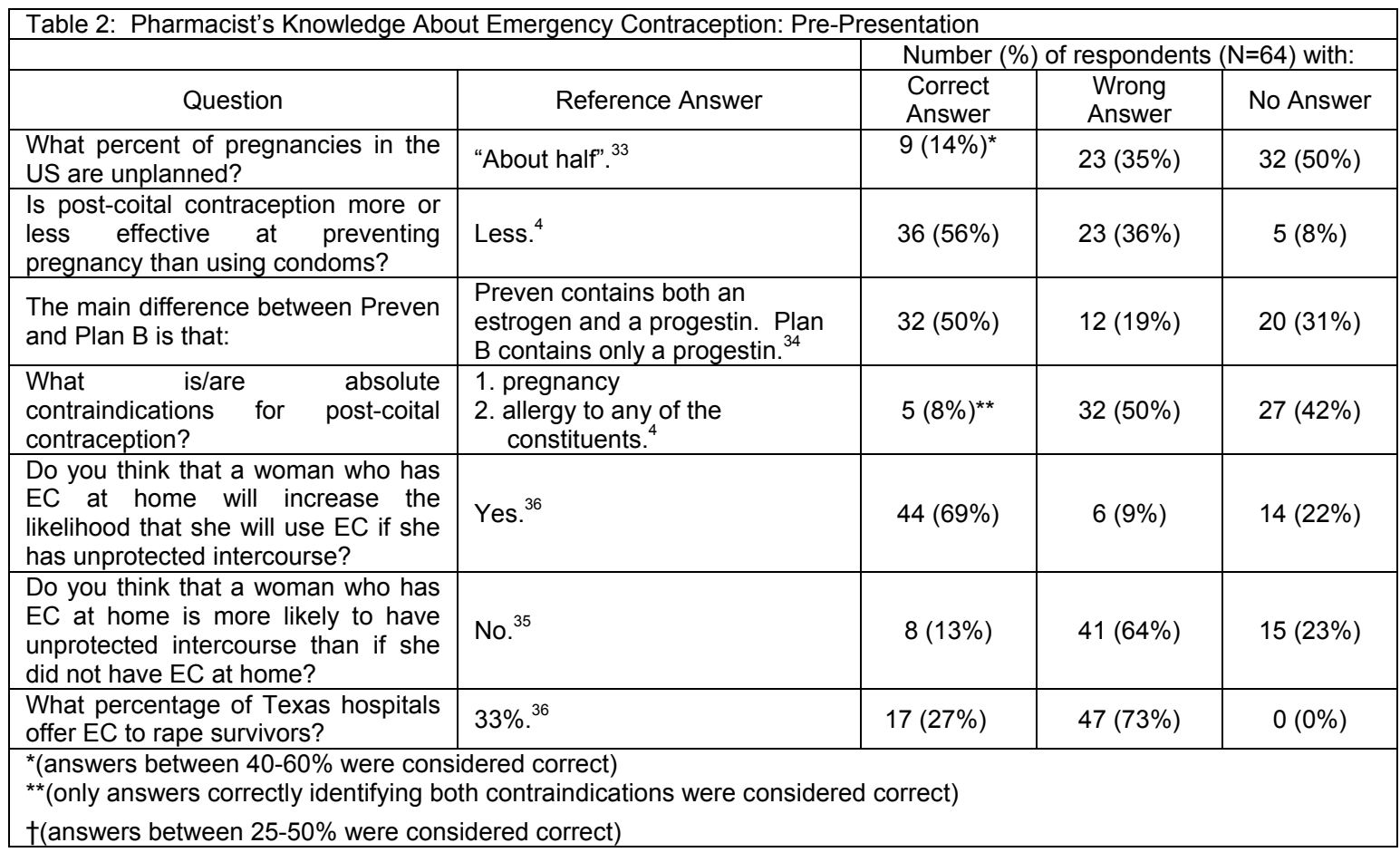

\begin{tabular}{|c|c|c|c|c|c|}
\hline Question: & \multicolumn{2}{|c|}{$\begin{array}{l}\text { Number of pharmacists }(\mathrm{N}=64) \\
\text { who answered Pre-Presentation: }\end{array}$} & \multicolumn{2}{|c|}{$\begin{array}{l}\text { Number of pharmacists } \\
(\mathrm{N}=57) \text { who answered Post- } \\
\text { Presentation: }\end{array}$} & P-Value \\
\hline \multirow{3}{*}{$\begin{array}{l}\text { 1. Would you be willing to provide an } \\
\text { EC prescription written by a } \\
\text { physician? }\end{array}$} & Yes & $45(70 \%)$ & Yes & $48(84 \%)$ & \multirow{3}{*}{$p=0.08$} \\
\hline & No & $7(11 \%)$ & No & $6(11 \%)$ & \\
\hline & No answer & $12(19 \%)$ & No answer & $3(5 \%)$ & \\
\hline \multirow{3}{*}{$\begin{array}{l}\text { 2. Would you be willing to provide EC } \\
\text { over the counter? }\end{array}$} & Yes & $37(58 \%)$ & Yes & $42(74 \%)$ & \multirow{3}{*}{$p=0.04$} \\
\hline & No & $14(22 \%)$ & No & $12(21 \%)$ & \\
\hline & No answer & $13(20 \%)$ & No answer & $3(5 \%)$ & \\
\hline \multirow{3}{*}{$\begin{array}{l}\text { 3. Do you consider EC to be a } \\
\text { method of abortion? }\end{array}$} & Yes & $11(17 \%)$ & Yes & $12(21 \%)$ & \multirow{3}{*}{$p=0.80$} \\
\hline & No & $47(73 \%)$ & No & $41(72 \%)$ & \\
\hline & No answer & $6(9 \%)$ & No answer & $4(7 \%)$ & \\
\hline \multirow{3}{*}{$\begin{array}{l}\text { 4. Does Emergency Contraception } \\
\text { conflict with your religious views? }\end{array}$} & Yes & $9(14 \%)$ & Yes & $9(16 \%)$ & \multirow{3}{*}{$p=0.12$} \\
\hline & No & $45(70 \%)$ & No & $46(81 \%)$ & \\
\hline & No answer & $10(16 \%)$ & No answer & $2(4 \%)$ & \\
\hline \multirow{3}{*}{$\begin{array}{l}\text { 5. What is the most likely method of } \\
\text { action of emergency contraception? }\end{array}$} & $25(39 \%)$ & \multicolumn{4}{|c|}{$\begin{array}{l}\text { Believed that EC prevents ovulation or sperm from fertilizing an } \\
\text { egg }\end{array}$} \\
\hline & $22(34 \%)$ & \multicolumn{4}{|c|}{$\begin{array}{l}\text { Believed either that EC prevents implantation of an embryo or } \\
\text { causes expulsion of an implanted embryo }\end{array}$} \\
\hline & $17(27 \%)$ & \multicolumn{4}{|l|}{ No answer } \\
\hline 6. Would you provide EC to: & Yes & No & No Answer & & \\
\hline a. a married woman & $41(64 \%)$ & $7(11 \%)$ & $16(25 \%)$ & & \\
\hline b. an unmarried woman & $41(64 \%)$ & $8(13 \%)$ & $15(23 \%$ & & \\
\hline c. rape victim & $47(73 \%)$ & $1(2 \%)$ & $16(25 \%)$ & & \\
\hline d. a woman under 18 & $35(55 \%)$ & $12(18 \%)$ & $17(27 \%)$ & & \\
\hline e. a woman with children & $41(64 \%)$ & $7(11 \%)$ & $16(25 \%)$ & & \\
\hline f. a woman without children & $41(64 \%)$ & $6(9 \%)$ & $17(27 \%)$ & & \\
\hline
\end{tabular}

\section{DISCUSSION}

This is the first survey that we are aware of that has asked pharmacists in a region where EC is not widely available about their experience with, knowledge of, and beliefs about EC. These pharmacists were generally uninformed about EC and did not carry EC. Many women they saw were candidates for EC but never asked the pharmacist about it. Despite West Texas' lack of EC availability, it is not unreasonable to assume that these pharmacists have been exposed to these controversies in the local media. It is interesting that five respondents $(8 \%)$ worked for pharmacies with a policy on the provision of post-coital contraception but did not actually carry EC. It would have been interesting to hear specific information about those 
policies, as this dichotomy by itself is an indication of conflicting values.

A survey of pharmacists in New Mexico, where EC is more widely available, generally showed positive attitudes and beliefs about EC. ${ }^{19}$ Those that participated in a state-approved EC prescribing training program had higher knowledge scores about EC. A survey of Thai pharmacists also showed generally poor knowledge of EC. ${ }^{21}$ A survey of United Kingdom pharmacists revealed that despite it's a wide availability, only $44 \%$ had received training in $\mathrm{EC}^{22}$

Fourteen percent of our pharmacists said that EC conflicts with their religious views, and we were not surprised that our presentation did not significantly alter their beliefs. Pharmacists who object to dispensing an EC prescription believe they have the right not to fill prescriptions that violate their beliefs. ${ }^{1}$ Yet others feel this type of conscientious objection to fill a valid prescription is not in a patient's best interest or safety. ${ }^{23}$ In Washington State, where pharmacists are allowed to enter into collaborative prescribing agreements with physicians, the majority of surveyed pharmacists indicated that they derive a high satisfaction from providing EC. ${ }^{17}$ The most common reason given was "meeting patients' needs." Six states currently protect a patient's right to receive EC from a pharmacist, and four states currently allow a pharmacist to refuse to fill an EC prescription. ${ }^{24}$ In 2005, sixteen states introduced some type of legislation to permit either pharmacists or pharmacies to refuse to fill a valid prescription based on personal beliefs. ${ }^{2,25}$ Both the American Society of Health System Pharmacists and the American Pharmacists Association endorse referring patients to other pharmacists or pharmacies in cases where filling the prescription conflicts with a pharmacists religious or moral values. ${ }^{1,26}$

We were surprised that the presentation significantly increased the percentage of pharmacists who would provide EC over the counter. Minnesota also has a collaborative prescribing agreement, but about half of the surveyed pharmacists had reservations about dispensing EC over the counter. Cited reasons included discouraging regular contraceptive use, personal or moral objections to EC, patient safety, lack of knowledge about EC, and liability concerns. ${ }^{18}$

EC is available OTC in India, Norway, and Sweden.
Because EC is more effective the sooner it is used ${ }^{27}$ and because privacy issues discourage some women from visiting a physician, ${ }^{28}$ some have theorized that OTC access to EC would prevent more unwanted pregnancies than if it was only available by prescription. ${ }^{29}$ One randomized trial demonstrated that pharmacy access (specifically, the ability to obtain EC from a pharmacy without prescription) did not decrease the pregnancy rate, nor did it increase sexual activity. ${ }^{30}$ This contradicts those who have suggested that wider availability of EC will encourage adolescents to practice risky sexual behavior $^{31}$ or discourage physicians from screening for sexually transmitted diseases. ${ }^{32}$ The FDA has approved EC for "behind-the-counter" distribution to women 18 or older.

Our study is limited by the fact that we surveyed a convenience sample of pharmacists who may have been influenced by a recall bias regarding patient encounters. Furthermore, our survey sample may not be representative of the entire population of West Texas pharmacists. Our survey was not tested for validity or test-retest reliability. Many of our calculations did not reach statistical significance. A larger survey group might give more power to our study.

Our survey also had many non-answers to several questions. Did the pharmacists who did not answer the knowledge questions (i.e.: the $31 \%$ who did not know the difference between Preven and Plan B) prefer not to answer, or was that an indication that they did not know the correct answer? We also had many non-answers to the more sensitive questions regarding beliefs. For example, when asked if they would be willing to provide OTC EC, $20 \%$ did not answer. Did these 13 object to the question? Did they not understand the question or believe the issue to be more complex than stated? Were they just unsure about the implications of selling EC over the counter? We only gave them "yes" or "no" choices and will never know.

\section{CONCLUSIONS}

We surveyed a sample of pharmacists from West Texas about EC. We found a general lack of knowledge about the biology, safety, and efficacy of EC. Fourteen to seventeen percent of our respondents were opposed to EC in general. Although a presentation did increase the percentage that would be willing to provide EC over the counter, it did not significantly change their beliefs.

\section{References}

1. Cantor J, Baum K. The limits of conscientious objection - may pharmacists refuse to fill prescriptions for emergency contraception? N Engl J Med 2004;351:2008-12.

2. Charo, RA. The celestial fire of conscience - refusing to delivery medical care. N Engl J Med 2005;352:2471-3.

3. Knecht L, Myrick M. Protesters fight pharmacy. Available at: http://www.ntdaily.com/vnews/display.v/ART/2004/02/03/40/401f3ebb7558e. Accessed February 5, 2004.

4. Glasier A. Emergency postcoital contraception. N Engl J Med 1997;337:1058-64.

5. Swahn ML, Westlund P, Johannisson E, Bygdeman, M. Effect of postcoital contraceptive methods on the endometrium and the menstrual cycle. Acta Obstet Gynecol Scand 1996;75:738-44. 
6. Marions L, Cekan SZ, Bydgeman M, Gemzell-Danielsson K. Effect of emergency contraception with levonorgestrel or mifepristone on ovarian function. Contraception 2004;69:373-7.

7. Gemzell-Danielsson K, Marions L. Mechanisms of action of mifepristone and levonorgestrel when used for emergency contraception. Hum Reprod Update 2004;10:341-8.

8. Kahlenborn C, Stanford JB, Larimore WL. Postfertilization effect of hormonal emergency contraception. Ann Pharmacother 2002;36:465-70.

9. Trussell J, Ellertson C, Dorflinger L. Effectiveness of the Yuzpe regimen of emergency contraception by cycle day of intercourse: implications for mechanism of action. Contraception 2003;67:167-71.

10. Emergency Oral Contraception. ACOG Practice Bulletin 2001; No 25. In: 2001 Compendium of Selected Publications. The American College of Obstetricians and Gynecologists 2001; pp 462-33.

11. Calis KA. Pharmacists and emergency contraception. N Engl J Med 2005;352:942-3.

12. Davey M, Belluck $P$, Hart A, et al. Pharmacies balk on after-sex pill and widen fight. The New York Times. 2005 Apr 19;Sect A:1 (col. 1).

13. Harrison T. Availability of emergency contraception: a survey of hospital emergency department staff. Ann Emerg Med 2005;46:105-10.

14. Beckman, LJ, Harvey M., Sherman CA, Petitti DB. Changes in providers' views and practices about emergency contraception with education. Obstet Gynecol 2001;97:942-6.

15. Foster DG, Landau SC, Monastersky N, Chung F, et al. Pharmacy access to emergency contraception in California. Perspectives on Sexual and Reproductive Health 2006;38:46-52.

16. Aiken AM, Gold MA, Parker AM. Changes in young women's awareness, attitudes, and perceived barriers to using emergency contraception. J Pediatr Adolesc Gynecol 2005;18:25-32.

17. Sommers SD, Chaiyakunapruk N, Gardner JS, Winkler J. The emergency contraception collaborative prescribing experience in Washington State. J Am Pharm Assoc 2001;41:60-6.

18. Kumar AS, Hall LC, LePage A, Lim, PC. Providing emergency contraceptive pills "behind-the-counter": opinions among Minnesota healthcare providers. Contraception 2003;68:253-9.

19. Borrego ME, Short J, House N, Gupchup G, et al. New Mexico pharmacists' knowledge, attitudes, and beliefs towards prescribing oral emergency contraception. J Am Pharm Assoc 2006;46:33-43.

20. U.S. Census Bureau. Available at: http://www.census.gov/popest/cities/SUB-EST2004-4.html. (Accessed January 5, 2006).

21. Ratanajamit C, Chongsuvivatwong V. Survey of knowledge and practice on oral contraceptive and emergency contraceptive pills of drugstore personnel in Hat Yai, Thailand. Pharmcoepidemiol Drug Saf 2001;10:149-156.

22. Ralph SG, Preston A, Clarke J. Over-the-counter advice for genital problems: the role of the community pharmacist. Int J STD AIDS 2001;12:513-5.

23. Greenberger M, Vogelstein R. Pharmasict refusals: A threat to women's health. Science 2005;308:1557-8.

24. Summary Of State Actions Related To Pharmacist Refusals. Available at: http://www.plannedparenthood.org/pp2/portal/files/portal/media/factsreports/fact-050418-pharmacist-refusals.xml. (Accessed January 5, 2006).

25. State policies in brief: Refusing to provide health services. New York: Alan Guttmacher Institute, September 1, 2004. Available at: http://www.guttmacher.org/statecenter/spibs/spib_RPHS.pdf (Accessed January 5, 2006).

26. Manasse HR Jr. Conscientious objection and the pharmacist. Science 2005;308:1558-9.

27. Rodrigues I, Grou F, Joly J. Effectiveness of emergency contraceptive pills between 72 and 120 hours after unprotected sexual intercourse. Am J Obstet Gynecol 2001;184:531-7.

28. Sucato GS, Gardner JS, Koepsell TD. Adolescents' use of emergency contraception provided by Washington State pharmacists. J Pediatr Adolesc Gynecol 2001;14:163-9.

29. Jones RK, Darroch JE, Henshaw SK. Contraceptive use among U.S. women having abortions in 2000-2001. Perspect on Sex Reprod Health 2002;34:294-303.

30. Raine TR, Harper CC, Rocca CH, et al. Direct access to emergency contraception through pharmacies and effect on unintended pregnancy and STIs: a randomized controlled trial. JAMA 2005;293:54-62.

31. Iffy L. Emergency contraception: politics trumps science at the U.S. Food and Drug Administration. Obstet Gynecol 2004;104:1103-4.

32. Stammers T. Emergency contraception from pharmacists misses opportunity. BMJ 2001;322:1245.

33. Stenchever, MA, Droegemueller W, Herbst AL, Mishell, DR, Jr. Comprehensive Gynecology. 4th ed. St. Louis: Mosby; 2001. p 296.

34. Randomised controlled trial of levonorgestrel versus the Yuzpe regimen of combined oral contraceptives for emergency contraception. Task Force on Postovulatory Methods of Fertility Regulation. Lancet 1998;352:428-33.

35. Glasier A., Baird D. The effects of self-administering emergency contraception. N Engl J Med 1998;339:1-4.

36. Where can a woman go? Reproductive services in Texas hospitals. A Project of Access Texas and the TARAL Education Fund; 2001. 